\title{
The Ethiopian Developmental State: Requirements And Perquisites
}

\author{
Tsehai Alemayehu, Savannah State University, USA
}

\begin{abstract}
The paper will take a close look at Prime Minister Zenawi's recent proposal of building a development state in Ethiopia with a view to determining whether such a scheme is practicable or even desirable in present day Ethiopia.
\end{abstract}

Keywords: African Economic Development; Ethiopia; Developmental State; Meles Zenawi; Neoliberalism

\section{BACKGROUND}

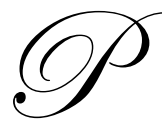

rime Minister Meles and with him the government of Ethiopia, seem to be set to change course and make public a new paradigm to guide public policy for the development of Ethiopia. A decade and half after he presented his EPRDF as the antitheses of the proudly socialist and collectivist Dergue, and nearly 6 years after his well publicized squabble with former President Negaso Gidada over the latter's preferences for left of center policy over the prime minister's then newly reaffirmed free market agenda, Mr. Meles now tells Ethiopians and indeed Africans everywhere that market based strategies are at a dead end in Africa.

The prime minister's analysis does not end simply at the prognosis state, identifying the obvious failure of the African economy and assigning appropriate blame for such failures. He goes a step further and proposes a new bold paradigm to yank Africa out of its dead end course and to place it on new path to its ultimate renaissance. According to the prime minister, the development paradigm which holds the greatest promise for Africa is the political economy of the developmental state.

Meles' paper broke new ground on more than one level. The very notion of a head of government placing his thoughts in the public domain for public discussion is unheard of in Ethiopia and quite a rare event for Africa at large. Not since those heady days of African independence in the late 1950s and 1960s have we seen African leaders who have had the courage of conviction to engage their publics in intellectual debate regarding the fate of their nations. Some have argued that the paper was never intended for Ethiopian audiences but foreign consumption. They point to the prime minister's choice of the English language, to the fact that he first presented the paper in Britain and that he has yet to discuss it within Ethiopia as evidence that this was meant as a sort of publicity stunt to impress his other constituencies with his intellectual prowess and not a proposal to his people for their consideration and feedback.

Regardless of whatever other considerations might have motivated the release of the document, the proposal constitutes new ground. For half a century, African policy discussions were essentially limited to the debate of whether Africa would be better of following in the foot prints of the colonial masters and adopt capitalist institutions, or if the socialist alternative could accelerate development in Africa. Meles' interjection appears to introduce a third alternative and promises to reenergize the debate. Given the current political environment in Ethiopia, some quickly reacted by expressing their doubt whether Meles' developmental state really resulted from a disappointment over the failure of the neo-liberal paradigm and questioned whether it constitutes a legitimate change of heart. Still others have pronounced that the prime minister's thesis shows that he is poised to return to his more natural and more comfortable socialist intellectual base.

Before embarking on the examination of Meles' new development manifesto, it would be appropriate to point to several factors which might render this commentary to be presumptive and possibly incomplete. For 
starters, even though Meles produced quite a hefty nearly 50-page document, the document clearly is an excerpt from a much larger manuscript which is likely to be several hundred pages when completed. The document leaves out several chapters, giving us only the chapter headings. In other instances, it includes the conclusions of key chapters without the benefit of the detailed discussion on which the conclusions are based. In several instances, large chunks of chapters are included, thus allowing the reader to appreciate both the logic of the specific argument presented but also giving the reader the opportunity to get a glimpse into the thought processes and the argumentation skills of the author. Even with so much missing, the document which was selectively extracted and placed in the public domain unambiguously points to what is in the author's mind. Yet, it is possible and even likely that what may appear to be errors in the author's logic or gaps in the evidence may in reality be succinctly argued elsewhere in the full document.

The reader is also bound to have a presumptive predisposition on account of who the author is. Although he is as well versed as any in the theoretical and empirical literature of the subject he writes about, it is rather difficult for the reader to pursue the contents of the paper as though it were just another contribution to the literature by another academic. As the political leader of Ethiopia for a decade and a half, many a commentator including this one have taken this document to constitute a basis for drawing a blueprint for organizing the political and economic life of Ethiopia going forward. Indeed, even though the author consistently posits his argument in the context of the broader African region and cites regional anecdotes and regional data to make his argument, this commentary cannot help but be influenced by what is known of his government's policy and the performance of Ethiopian political economy while mauling over the content of the document.

\section{EVENTS WHICH TRIGGERED THE SEARCH FOR AN ALTERNATIVE}

The published literature which credibly reports on the ideology of Meles' TPLF in the years preceding its victory over the Dergue is rather sparse and often speculative. The consensus view in that admittedly sparse literature is that the TPLF started as a Marxist-Leninist political movement and operated as such until the eve of its ascendance to state power in 1991. Only in the final days of 1989 did the TPLF began to make an about turn and presented itself to the world as a liberal democratic movement.

Perhaps it was the stark reality of the collapse of the Soviet Union. Perhaps it was a calculated move designed to secure the support of the United States in the final days of the cold war. Perhaps it is a result of Meles' heightened profile within the organization and the organization subsequently reflecting more of his personality and his vision. Few outside the inner sanctum of the TPLF circle know for sure why such a change took place. And those on the inside have yet to publish the definitive history of that turnabout. While the cause still remains a subject of much speculation, by 1990, it was obvious even from a distance that the TPLF had decided to follow a different cause. It soon began a campaign to promote itself as a born again, democratic and neo-capitalistic alterative to the Dergue.

Although many political types and even a large part of the population quickly began to grumble about the Dergue-like economic policy and the political control regimes that the TPLF/EPRDF put in place, Meles' government never wavered on its declared commitment to a free market economic system during the first ten years of his rule. Only the highly publicized fallout between the then President Negaso Gidada and Prime Minister Meles in 2001 gave the public a faint hint that the EPRDF was reexamining its course. Even then, it appeared that Meles was only reaffirming and strengthening his party's commitment to what he calls now the neo-liberal economic paradigm.

His current proposal constitutes a fundamental change from the officially pronounced framework and seems to be born as a result of his frustration with that same neo-liberal framework. He seems to rue the fact that in spite of blind adherence with the prescriptions of the neo-liberal doctrine, there has been little improvement in the economic prospects of African countries, presumably including that of his own country. Even though he did not so state in this particular document, he has also repeatedly spoken on other occasions of his disappointment with the neo-liberal obsession with electoral politics to the exclusion of everything else. But it is clear that his greatest gripe with the blueprint the EPRDF has faithfully followed in the early years pertains to the lack of adequate economic progress in his country and elsewhere in Africa. 
Meles throws a litany of charges at the feet of the neo-liberal development model to highlight the many ways it has failed Africa. He points to the fact that since African countries began to adopt policies mimicking the neo-liberal Washington consensus, the region's economy has been growing at a slower pace than any other region's economy. He also charges that the neo-liberal model does not hold any promises for facilitating the movement of developing countries further up on the technology ladder.

He seems to be particularly incensed with the neo-liberal obsession with minimizing rent seeking behavior by tying the hands of government in the face of pervasive market failures which are a much more substantial hindrance to development. He argues that in Africa, in nearly every sector including agriculture, finance, manufacturing and export trade, there exists substantial market failure which is essentially responsible for the dismal performances of these sectors. Meles emphatically states that only a developmental state can eliminate rent-seeking behavior and still be able to reduce or eliminate market failure.

There is no attempt to provide evidence for either of these presumed attributes of a developmental state. Further, because the chapter dealing with the introduction of the developmental state paradigm is missing, the reader has no bases for judging for himself whether such a system holds even the possibilities for making such a leap of faith. As an aside, it is interesting to note that the author seems to ignore the fact that rent-seeking behavior does not, in and of itself, retard economic development. On the contrary, economic rent has often been the wellspring of capital accumulation which is known to have made possible sustained development in many of what are today the most developed of countries.

One of the most extensive extractions appearing in this document is taken from the chapter on 'Democracy, Developmental State and Development'. In his attempt to highlight the limited value of democratic governance and the heightened significance of social capital and civic virtue to economic development, Meles takes the reader on a guided tour of the socio economic history of Italy. He then surmises that the stark differences in the present economic fortunes of northern and southern Italy arise from the fundamental differences in the respective endowments of social capital and civic virtue of the two regions which are otherwise governed under the same democratic constitution. He concludes on the bases of the differences in the economic performances of the two Italian regions that democracy is not a sufficient condition for development.

In this same chapter, commenting on the connection between democratic governance and economic development, Meles alerts the reader to two distinct tendencies associated with democratic governance each of which can retard the pace of economic development. On the one hand, there is the well recognized need for stability and predictability even for the best of policies to yield meaningful outcomes. Yet, by definition, electoral democracy is prone to frequent changes in government and hence to instability in the policy environment. He thus proposes the formation of a defused rural based stable coalition which will advance the interest of agriculture given the orientation of the coalition and will provide the stability required for development.

Secondly, he emphatically declares that the coalition must be independent from the influences of the private sector, which this reader understands to mean the urban private sector (as the rural farmer is already ensconced at the center of power as noted earlier). This conclusion seems to flow from his concern over the susceptibility of "democratic politics becoming riddled with patronage and rent seeking" especially in its urban context.

The conclusion he reaches from this analysis is that a state that can be "both democratic and developmental ... (only if it takes) the form of a dominant party or dominant coalition democracy"...in other words, a one party state, so to speak

One can disagree with this line of thinking at several levels. First, one can take issue with the democratic character of a "diffused rural coalition". Such a coalition, especially if it is overlaid on to the reality of rural Ethiopia, is unlikely to have any democratic content except in name. Power would be absolutely and relatively concentrated at the center. This of course is the antithesis of democratic governance. 
The other key feature of the ruling coalition which was spelled out in the document, namely the exclusion of the urban private sector from the coalition, is also problematic. By Meles' own reckoning, the success of the developmental state is to be measured primarily by its ability to transform the economy from a low-tech, lowproductivity peasant economy into a capital intensive, high-productivity, export driven manufacturing economy. All of the desired outcomes are the attributes of the urban private sector. One thus must ask whether it is feasible for a state to transform its economy to the very thing it must first seek to undermine in the formation of the governing coalition? Meles has anticipated this question and states that he does not intend for "the governing coalition ... (to) be hostile to the private sector". And yet that is exactly what he is proposing.

In a fascinating if at times confusing segment of his essay, he argues that a developmental state cannot be very effective in the pursuit of its developmental mission except if it were democratic. He thus argues that a developmental state would naturally prefer to be democratic. And yet he had earlier written that a developmental state requires the stability which, in a democracy, can only come with being a one party state---something he would rather call a dominant party democracy. It seems that in his desire to show the logic of undermining the urban economy on account of his sense of its predisposition to patronage and rent-seeking, he has placed himself in a logically untenable corner.

\section{THE APPEAL OF THE DEVELOPMENTAL STATE MODEL}

Meles does not just profess his admiration for the developmental state. He engages in a spirited discourse trying to relate to the reader the virtues of that development paradigm by pointing to the specific successes of those who have faithfully followed it. Six of the twenty one chapters of this manuscript are dedicated to an analysis of the social, economic and political histories of two of the most notable adherents of the developmental state paradigm, namely, Taiwan and South Korea. He goes to great length expounding on the condition of their respective economies prior to embarking on the path to developmental statehood, their shared colonial experiences, and the political institutions which launched the countries on the course of developmental statehood.

The reader here is presumed to be well aware of the spectacular economic successes of Taiwan and Korea as well as those of the other Southeast Asian countries over the last 50 years. As such it is not surprising that a leader such as Meles who prides himself as a sort of economic policy wonk, would be so smitten with that record of success that he would want to emulate them. So great were their performances and so unconventional their approach, many have taken to calling that entire episode a developmental miracle.

One suspects however, that Meles' methodical account of their successes is meant to serve as a marketing tool for selling the virtues of his notion of the developmental state rather than to expound on the policy framework which planted and nurtured the economic miracle in these two nations.

Perhaps that is why he goes to great length to highlight the centrality of agricultural development at the onset of the development programs in both Taiwan and Korea and the role of the state to the success of that effort. The author points out the two countries owe significant parts of their good fortunes to their colonial experiences under Japan. Meles argues that because Japan was interested in extracting agricultural surplus from the colonies, 'it deeply penetrated the rural areas and established a very powerful, effective and repressive state apparatus down to every village of the colonies". He believes that it is this colonial experience which "paved the way for the creation of a (post-colonial) state that is both effective and towers like a colossus on society." One cannot help but be struck by the similarity of this account of the conditions in Taiwan and Korea 60 years ago with the reality of present day Ethiopia, where one finds a network of political and developmental cadres in every village across Ethiopia.

This portion of the document credited the activist governments in both Taiwan and Korea with successful land reform programs which emphasized equity over the establishment of what could be more efficient large commercial farms. The two governments are also recognized for correcting market failures through agricultural credit schemes and for intervention in the market aimed at stabilizing farm prices. The selective use of incentives and disincentives to direct the economy is singled out as the primary factor responsible for much of the success of these economies both in the early years of reliance on agriculture as well as in the push to industrialize through exporting. 
Meles makes it a point to highlight the fact that in both Taiwan and Korea, the developmental states were led by stable governing coalitions which were brought together under external threats and ruled for decades. Hence the experiences of both of these countries plus that of Japan as well as a few others in the region fall neatly within Meles' developmental state paradigm both in form and in function. Leading one to conclude that this is a tried and true paradigm worthy of emulation.

As a contrast to the East Asian miracle economies, the reader is offered the sorry state of the economies of the African countries. Meles places the miserable conditions of the African economies squarely at the feet of the failed neo-liberal paradigm, the international financial institutions which promoted the free market doctrine and the predatory states which presided over the destruction of their economies. He argues that "the African state which emerged from colonialism... was a predatory state driven by the logic of maximizing rent for the rulers (and empowered by) its intermediary status...between the people and the international system".

The push by the international financial institutions for reform along the neo-liberal model, it is argued, was the cause of the utter collapse of the African economies a decade or so after independence. Although he acknowledges that economic conditions across the region were poor and deteriorating in the years before economic reform, Meles' entire thesis is dedicated to providing the theoretical and the empirical evidence that neo-liberal reform in Africa was doomed to fail from the outset and has been a failure.

Again he begins his argument by reminding the reader of his central hypotheses that sustained development must start with the development of agriculture and that pervasive market failures and structural bottlenecks result in vicious circles which retard the development of agriculture and all other sectors. Meles goes on to argue that the neo-liberal paradigm which prescribes what he calls 'a night watchman state' essentially condemns the African economies to remain stuck in their current dead end state indefinitely.

His characterization of what ails African agriculture is well supported both empirically and theoretically. He highlights the prevalence of high transportation costs as a result of the dismal state of transportation infrastructure, the lack of access to capital and dearth of reliable market information. The neo-liberal reforms which concentrated on price liberalization have no means for addressing structural bottlenecks such as these. Consequently, the kind of radical transformation in agriculture that is required for the transformation of the economy was never triggered by the reforms.

Where his argument is weakest is when he tries to explain why finance and investment are also fairing so badly under the reform program. He points to the excess liquidity of the banking system across the region while at the same time there is a big spread between the lending and deposit rates of interest. In a somewhat jumbled logic, Meles states that the excess liquidity is partly a result of the low demand for credit associated with the decimation of the traditional credit customers of banks. Also contributing to this outcome is the reluctance of banks to take risk given the large non-performing loans they carry as a result of the distressed conditions of their traditional customers. The fact that both of these phenomena are absent on the ground might explain the absence of bankable projects but do not explain why banks continue to attract loanable funds. This gap in logic is further evidenced when he also speaks of the prevalence of high real lending rates and of wide spreads between the lending and deposit rates in Africa today. It is as if the supply side of the credit market is independent from the low deposit rate. If it were not so, then the low deposit rate (low cost of loanable funds from the banks' vantage point) would lead to credit being offered at lower real interest rates. That of course should close the interest rate spread and also help mop-up the problematic excess liquidity.

It thus seems that neither the old pre-reform predatory state nor the post-reform night watchman state served the development needs of Africa well. He concludes this section by pointing out that the only option left for Africans seeking a way out from their pitiful economic circumstances is the developmental state - an alternative which has been proven to be effective by the experiences of more than half a dozen countries in East and Southeast Asia. 


\section{THE BLUEPRINT FOR A DEVELOPMENTAL STATE}

Meles denies the possibility of a blueprint for the establishment of a development that can fit the needs of all African states. Nonetheless, he identified key preconditions for the establishment of such a state. Some of these pertain to phenomenon internal to the African state while others are external.

First on his list of preconditions is the need to dare to think beyond the traditional framework. He seems to be particularly incensed with the fact that Africans tend to easily succumb to the changing whims of external actors. So he challenges African leaders to think outside the box and think of alternative approaches when a strategy fails to give the intended results. The other changes required in the internal conditions include the establishment of agrarian democracies (in a sense the flip side of the Marxist proletarian democracy) and the rebuilding of the development capacity of the African state.

On the external side, Meles believes that the kinds of radical transformations that are called for require the support and understanding of the international community. Given the need to rump up infrastructure expenditures and to reorient the economy towards exports, the state must secure the assistance and understanding of international development partners. Such partners must provide both additional development assistant and show some flexibility in the application of international trade and investment rules to give the infant industries of the developmental state a chance to grow and compete globally.

$\mathrm{He}$ is bullish on the ability of many African states to garner the external support and to muster the energy required to realign the internal conditions to comply with the requirements of a developmental state.

\section{CONCLUSION}

This commentator and others initially took the Prime Minister's paper to constitute not a legitimate change of heart but a return to more comfortable grounds. At first glance his proposal appeared to be an attempt to justify the heavy hand of the EPRDF in the Ethiopian economy - an attempt to couch in intellectual context and thereby lend gravitas to a controversial policy framework already in place rather than a proposal for a change of course.

While one can question some of the assumption which undergird key features of his particular developmental state paradigm, there is no doubt that the developmental state paradigm is a well established alternative to the neo-liberal model. The developmental state model is note quite the voodoo-economics some make it out to be.

Perhaps the most controversial feature of Meles' developmentalism is what it portends on the political domain. Given the events which have been unfolding over the last two years in Ethiopia, many a citizen is likely to be skeptical about a scheme which seems to propose a perpetual one-party state even when one accepts the virtues of the developmental state model as it relates to improving the economic conditions of Ethiopia.

Given the polarized state of the Ethiopian electorate today, reasonable dialogue is not possible. Reasonable citizens and citizen groups who would otherwise acknowledge the inevitability of tradeoffs, including tradeoffs between economic and political objectives, find it difficult to engage in the needed dialogue in the current political circumstances. Perhaps Mr. Meles missed the boat when he did not unveil his thoughts during the campaign two years ago and asked the Ethiopian people to be the judge.

\section{AUTHOR INFORMATION}

Tsehai Alemayehu has been employed at Savannah State University since the mid 1980s. He studied economics at the University of Kentucky and has worked in a number of institutions including at the National Bank of Ethiopia where he directed the research department until the mid 1980s. 


\section{REFERENCES}

1. Araia, Ghelawdewos, Reflection on “African Deelopment: Dead ends and New Beginings', http://www.africanidea.org/ Institute for Development and Educatiion for Africa, August 23, 2006

2. Evans, Peter. (1995). Embedded Autonomy: States and Industrial Transformation. Princeton: Princeton University Press. Ch. 1.

3. Kurtz, Marcus, State Developmentalism Without a Developmental State: The Public Foundations of the "Free Market Miracle" in Chile, Latin American Politics and Society, Summer 2001

4. Leenco Lata, Extracting PM Meles Zenawi's Extracts, The Reporter, February 10 and 17, 2007.

5. Meles Zenawi, African Development Dead Ends and New Beginings, lecture presented at a forum organized by the Initiative for Policy Dialogue, Manchester, England, August 19, 2006.

6. Mkandawire, Thandika, Thinking About Developmental States in Africa, Paper presented at UNU-AERC workshop on Institutions and Development in Africa held at UNU headquarters, Tokyo, Japan, October 1415,1998

7. Polidano, C. (2001). Don't Discard State Autonomy: Revisiting the East Asian Experience of Development. Political Studies. Vol. 49. No.3. 1: 513-527.

8. Onis, Ziya. (1991). The Logic of the Developmental State. Comparative Politics. 24. no. 1. pp. 109-26.

9. Minns, John, (2001). Of miracles and models: the rise and decline of the developmental state in South Korea. Third World Quarterly. 22(6): 1025-1043.

10. Kim, Yun Tae, (1999). Neoliberalism and the decline of the developmental state. Journal of Contemporary Asia. 29(4): 441-461.

11. Wade, Robert, (2003). What strategies are viable for developing countries today? The World Trade Organization and the shrinking of 'development space'. Review of International Political Economy. 10 (4). pp. 621-644.

12. Weiss, Linda. (2000). Developmental States in Transition: adapting, dismantling, innovating, not 'normalising'. Pacific Review. 13(1): 21-55.

13. Wong, Joseph. (2004). The adaptive developmental state in East Asia. Journal of East Asian Studies. 4: 345-362.

14. Woo-Cumings, Meredith. (1999). The Developmental State. Cornell University Press. 
Journal of Business \& Economics Research-August, 2009

Volume 7, Number 8

\section{NOTES}

